\title{
Prevention of outburst floods from periglacial lakes at Grubengletscher, Valais, Swiss Alps
}

\author{
Wilfried Haeberli, ${ }^{1}$ Andreas Kä̈̈в, ${ }^{1}$ Daniel Vonder Mühll,${ }^{2}$ Philip Teysseire ${ }^{3}$ \\ ${ }^{1}$ Department of Geography, University of Zürich-Irchel, CH-8057 Zürich, Switzerland \\ ${ }^{2}$ Laboratory of Hydraulics, Hydrology and Glaciology, ETH-Zentrum, CH-8092 Zürich, Switzerland \\ ${ }^{3}$ Teysseire and Candolfi Engineers, CH-3930 Visp, Switzerland
}

\begin{abstract}
Flood and debris-flow hazards at Grubengletscher near Saas Balen in the Saas Valley, Valais, Swiss Alps, result from the formation and growth of several lakes at the glacier margin and within the surrounding permafrost. In order to prevent damage related to such hazards, systematic investigations were carried out and practical measures taken. The evolution of the polythermal glacier, the creeping permafrost within the large adjacent rock glacier and the development of the various periglacial lakes were monitored and documented for the last 25 years by photogrammetric analysis of annually flown high-resolution aerial photographs. Seismic refraction, d.c. resistivity and gravimetry soundings were performed together with hydrological tracer experiments to determine the structure and stability of a moraine dam at a proglacial lake. The results indicate a maximum moraine thickness of $>100 \mathrm{~m}$; extremely high porosity and even ground caverns near the surface may have resulted from degradation of sub- and periglacial permafrost following $19 \mathrm{th} / 20 \mathrm{th}-$ century retreat of the partially cold glacier tongue. The safety and retention capacity of the proglacial lake were enhanced by deepening and reinforcing the outlet structure on top of the moraine complex. The water level of an ice-dammed lake was lowered and a thermokarst lake artficially drained.
\end{abstract}

\section{INTRODUGTION}

A variety of ice- and debris-dammed periglacial lakes exist at the front or margins of glaciers as well as in permafrost areas of high-mountain regions. Outbursts of such proglacial, icemarginal or thermokarst lakes constitute a major natural hazard and can be associated with extreme discharge events (Lliboutry and others, 1977; Haeberli, 1983; Vuichard and Zimmermann, 1987; Evans and Clague, 1993; O'Connor and Costa, 1993). Outbursts of large ice-dammed lakes often take place through flotation of the ice dam followed by progressive enlargement of subglacial channels (Clague and Mathews, 1973; Spring and Hutter, 1981; Clarke, 1982; Evans, 1986), but smaller events may be due to sudden-break mechanisms causing especially high ratios between peak discharge and outburst volume (Haeberli, 1983). Breaching of moraine dams involves piping (progressive ground-water flow) within the morainic material, liquefied flow/slippage on steep slopes, and overtopping with retrogressive incision (Jackson and others, 1989; Clague and Evans, 1994; Haeberli, 1996). Glacier shrinkage induced by atmospheric warming may eliminate problems relating to ice-dammed lakes in some places but create new ones in others. Especially proglacial lakes, growing behind large terminal moraines built up by heavily debris-covered glaciers, constitute a recognizable and rapidly growing hazard in countries such as Nepal and Bhutan (Gansser, 1983; Hanisch and others, 1998; Yamada, 1998). Technical measures have been taken in some cases to mitigate the hazard (Lliboutry and others, 1977; Haeberli and Epifani, 1986; Reynolds and others, 1998).

On steep slopes covered with abundant loose sediments in the form of talus and moraines, the sudden emptying of even small lakes can lead to devastating debris flows (Haeberli, 1983, 1996). The densely populated Swiss Alps have repeatedly been affected by such floods and debris flows. A multitude of factors must be taken into account when assessing risks from such events (Haeberli, 1983; Haeberli and others, 1989). The corresponding hazard depends on potential flood volumes, outburst mechanisms, discharge development, erosional and depositional processes, slope and distance to human installations, and the nature and locations of artificial structures. One aspect, however, is common to many cases: the long-term evolution of potentially dangerous water bodies at the surface can be recognized at an early stage and systematically monitored. This approach offers possibilities of carrying out hazard prevention work in time.

Five major glacier floods and debris flows had affected the village of Saas Balen, Saas Valley, Valais (Fig. 1), during the 19 th and 20th centuries, repeatedly causing heavy damage to the community. The source area of these events is a glacial cirque situated $1400 \mathrm{~m}$ above and only about $3 \mathrm{~km}$ away. As a consequence of glacier recession and permafrost degradation, a number of lakes developed during the past decades in thick debris accumulations around the tongue of Grubengletscher. Flood prevention work was done at two of these lakes (Lakes No. 1 and 3) following the last outburst event in 1970. These measures proved to be successful during a period of intermittent glacier growth in the 1970s and early 1980s. However, new problems developed in recent years when glacier thinning started to accelerate again. Analysis of specially flown aerial photographs, together with geophysical soundings and hydrological observations, allowed the design of new pre- 




Fig. 1. Situation (Switzerland) and orthophoto map of the Gruben cirque between the Fletschhorn (3993 m a.s.l.) and Saas Balen (not visible). Numbers 1-6 refer to the periglacial lakes, letters $A-C$ to important springs related to hydrological investigations, and I to the injection point for tracer experiments. Lines $P_{1} P_{2}$ and $P_{3}$ are seismic refraction profiles. Geoelectrical d.c. resistivity soundings were taken along the seismic lines $P_{1}$ and $P_{2}$; gravimetric measurements were made along $P_{1}$ and $P_{2}$ and also perpendicular to these lines along the contour lines 2650 and 2770 m a.s.l. Air photos taken by Federal Office of Cadastral Surveys, 30 August 1991, flying height $8000 \mathrm{~m}$ a.s.l. 
ventive measures. The present paper summarizes the research which formed the basis for such hazard-prevention activity and addresses the construction work carried out at this high-mountain site (cf. detailed reports in German by Kääb and Haeberli, 1996; Kääb and others, 1996; Vonder Mühll and others, 1996; Haeberli and others, 1999a).

\section{SITE AND HISTORIGAL BAGKGROUND}

The region under study lies within a glacial cirque in which the tongues of Grubengletscher and of the Gruben rock glacier lie side by side (Fig. 1). Several lakes formed within this complex combination of polythermal glacier ice, thick morainic deposits and discontinuous permafrost. For historical reasons, the numbering of the lakes starts with the proglacial Lake No. 1, then proceeds up-glacier to the ice-marginal Lakes No. 2, 3 and 4 , and finally includes Lakes No. 5 and 6 in dead ice deposited within periglacial permafrost. Following two outbursts of ice-dammed Lake No. 3 in 1968 and 1970, an access road was constructed to enable flood prevention work and corresponding site investigations. The same road together with accumulated local knowledge also greatly facilitated projects of predominantly scientific interest (Barsch and others, 1979; Haeberli and others, 1979; Haeberli and Fisch, 1984; Haeberli, 1985; Kääb and others, 1997).

Grubengletscher (Fig. 1) flows from the summit of the Fletschhorn at $3993 \mathrm{~m}$ a.s.l to the bottom of the cirque at around $2800 \mathrm{~m}$ a.s.l. The accumulation area exposed to the northwest is assumed to be predominantly cold above about $3500 \mathrm{~m}$ a.s.l., with characteristic $10 \mathrm{~m}$ temperatures reaching $-10^{\circ} \mathrm{C}$ in the highest parts (Haeberli, 1975; Suter, 1995; Frauenfelder and others, 1998; Suter and others, 2001). Fast flow of thin and crevassed ice on the steep slopes, together with warmer firn temperatures in the lower accumulation area between about 3500 and $3200 \mathrm{~m}$ a.s.l., explains the predominantly temperate ice in the ablation area. However, a slightly cold surface layer $\left(10 \mathrm{~m}\right.$ temperatures between $-1^{\circ}$ and $-2{ }^{\circ} \mathrm{C}$ ), some $20-30 \mathrm{~m}$ thick, exists on the flatter glacier tongue which is frozen to the bed at its margin. Artesian water has been observed in boreholes which were drilled to the glacier bed in the transition zone between warm- and cold-based ice. The cold-based glacier margin indeed acts as an effective hydraulic barrier for the ice-marginal Lake No. 3, keeping the water pressure high in the central, warmbased part of the glacier. The glacier tongue rests on a thick sedimentary, permeable and deformable bed. D.c. resistivity soundings carried out at the bottom of boreholes drilled to the glacier bed (Haeberli and Fisch, 1984) indicate a total subglacial sediment thickness of about $100 \mathrm{~m}$ underneath the glacier tongue, which is typically about $50 \mathrm{~m}$ thick.

Ice-rich frozen ground within the adjacent Gruben rock glacier reaches depths of $>100 \mathrm{~m}$ (King and others, 1987) but may not be in contact with bedrock everywhere. Mean annual temperature at the permafrost table today is close to $-1^{\circ} \mathrm{C}$ but must have been colder during the Little Ice Age in order to explain the measured permafrost thickness (Barsch and others, 1979). Creep of the frozen sediments typically amounts to some decimeters per year at the surface, predominantly exhibits extending flow, and points to an overall rockglacier age measured in thousands of years (Haeberli and others, 1979; Kääb and others, 1997). Pronounced seasonal variations of surface velocities indicate some sliding or discrete shear, possibly on wet and deformable sub-permafrost sediments (Haeberli, 1985). Strain-rate components and surface-altitude changes for the time period 1970-95 (Kääb and others, 1997) reveal an overall tendency for the rockglacier surface to subside at a rate of a few centimeters per year. This is largely due to 20th-century warming and corresponding thaw settlement of ice-supersaturated debris in combination with vertical thinning as a consequence of predominant longitudinal extension.

In the area of former contact between the rock glacier and the more extended glacier during the maximum stage of the Little Ice Age around AD 1850, remains of buried ice are embedded on top of the permafrost. The thermokarst Lakes No. 5 and 6 developed in such massive ground ice. Here, permafrost was probably glacitectonically deformed and pushed upslope by the advancing cold-based margins of the Little Ice Age Grubengletscher. The resulting morphologically distinctive push moraine at the former line of contact between the glacier and the rock glacier is now creeping and sliding backwards into the topographic depression which was left by the glacier retreat during the past decades (Kääb and others, 1997; cf. Fig. 2). Temporary lakes sometimes form during the melt season within two permafrostfree areas in the background of the cirque and in between the tongues of the glacier and the rock glacier. Proglacial Lake No. 1 developed in front of, and within, the heavily debris-covered glacier tongue, on top of thick morainic debris and behind small terminal moraines probably deposited during the intermittent readvance of Alpine glaciers around 1890 and 1920. Lake No. 2 was a small ice-marginal pond in the 1960s and early 1970s but was completely filled by the intermittently readvancing ice margin in the late 1970s and 1980s. Lake No. 3 was dammed at its down-valley end by a mixture of frozen ground and glacier ice in the contact zone between the glacier and the rock glacier. Lake No. 4 fills episodically at the glacier margin where Grubengletscher enters the flat cirque floor from the much steeper rock slopes below the summit of the Fletschhorn.

Earlier sudden floods from the Gruben area occurred in 1829, 1868 and 1958 (Lichtenhahn, 1979). The 1958 event was due to Lake No. 3 overflowing its ice/permafrost dam. In the summer of 1968, Lake No. 3 emptied catastrophically by progressive enlargement of a subglacial channel. The lake outburst volume was roughly $170000 \mathrm{~m}^{3}$, causing a peak discharge of only about $10 \mathrm{~m}^{3} \mathrm{~s}^{-1}$ but eroding about $400000 \mathrm{~m}^{3}$ of debris within Holocene morainic material immediately below Lake No. 1 and within late-glacial morainic material near Grubenalp (bottom right corner of Fig. 1), at about mid-distance to the main valley. The resulting damage in the village of Saas Balen was heavy. A similar event from Lake No. 3 again took place in summer 1970 after closure of the subglacial channel during winter. This time, the peak discharge was about $15 \mathrm{~m}^{3} \mathrm{~s}^{-1}$ and the total volume eroded in morainic deposits amounted to about $100000-150000 \mathrm{~m}^{3}$. After the event, a tunnel was excavated through the basis of the damming ice margin, and later a large pipe was installed within the subglacial permafrost of this tunnel in order to keep the lake at a safe water level. At Lake No. 1, an artificial dam consisting of coarse blocks with a concrete outlet was constructed to prohibit retrogressive erosion in case of unpredictable floods from upstream lakes and ponds or subglacial reservoirs (Lichtenhahn, 1971, 1979; Röthlisberger, 1971, 1979, 1981; Haeberli, 1980). Annual airphoto flights at low altitude were initiated in 1970 to monitor the development of the conditions at the site. 

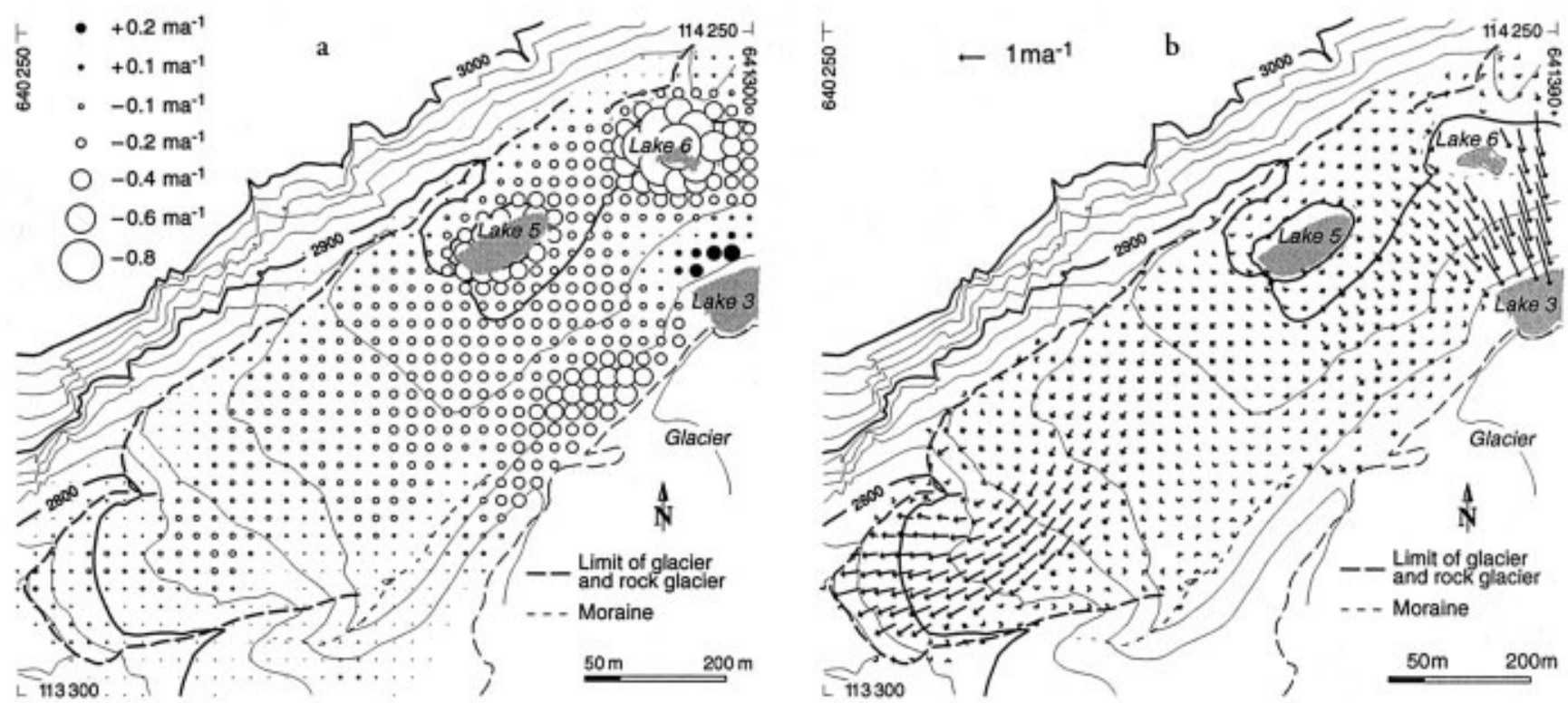

Fig. 2. Topography, surface elevation change and surface displacements on the Gruben rock glacier. (a) Topography of 1991 and changes in surface elevation during 1970-95 indicating different subsidence rates in the periglacial part (lower left) and the glacier-affected part containing massive remains of dead ice (upper right). (b) Surface displacements on the Gruben rock glacier during 1970-95 indicating different creep regimes of the periglacial part (lower left) and the glacier-affected part (upper right). The velocity field and the changes in surface elevation allow for an estimate of recent glacial impacts and related dead-ice occurrences on the rock glacier.

\section{OBSERVATIONS, MEASUREMENTS AND SOUNDINGS}

Photogrammetric analysis with multitemporal digital terrain models and simultaneous monoplotting in photogrammetric stereo models (for details of the newly developed methodology, cf. Kääb and others, 1997; Kääb and Funk, 1999) enabled the evolution of lake areas to be documented, changes in surface elevation to be determined and surface flow fields of the glacier and the rock glacier to be measured. The large moraine at Lake No. 1 was investigated using a combination of seismic refraction, geoelectrical d.c. resistivity and gravimetry to gain information about the thickness, internal structure and porosity of the morainic material. At this site, discharge and water-temperature measurements together with tracer experiments were also carried out.

The observations collected by these investigations and regular field inspections are described in the following. Thereby, the lakes are treated in a sequence along the general drainage direction, i.e. from the lakes higher in the drainage down to Lake No. 1. This makes it easier to understand the hazard potential at each lake which includes possible chain reactions along the drainage path from lake to lake. The safety of Lake No. 1, for instance, not only depends on the stability of its own outlet but also on processes relating to upstream lakes. Note that Lakes No. 6 and 4 independently of each other flow into Lake No. 3.

\section{Thermokarst Lakes No. 6 and 5}

During the mid-1960s, crevasses formed at the upper margin of dead-ice occurrences within the creeping permafrost area (cf. Fig. 2). Two corresponding depressions progressively enlarged, forming the thermokarst Lakes No. 6 and 5.

Lake No. 6 fills up only during winter and spring. When the lake is full of water, the frozen lake bottom starts leaking and the lake slowly empties through the permeable permafrost active layer, through remaining dead-ice layers or through the underlying permafrost. Freezing water seems to seal the bottom of the lake depression in late autumn.
Subsequently, the lake fills with water, ice and finally snow until melting starts in spring. At its deepest point, the bottom of Lake No. 6 has lowered continuously by about $1 \mathrm{ma}^{-1}$ since 1970; the related depression had an area of roughly $10000 \mathrm{~m}^{2}$ in the late $1990 \mathrm{~s}$ (cf. Fig. 2). Although the enlargement of the lake was accompanied by various manifestations of thermokarst development such as undercutting of ice walls by circulating lake water, melting and downwasting of exposed massive ice, small landslides in morainic material along the oversteepened lake shores, rock falls, or collapse phenomena in the permafrost active layer, signs of catastrophic emptying were never observed, or corresponding runoff changes were damped below critical levels by the retention function of the artificially regulated Lakes No. 3 and 1 lower in the drainage.

The surface of Lake No. 5 grew at an accelerating rate and asymmetrically towards the south, exposing there an increasingly high ice front. In 1994, the lake reached an area of $10000 \mathrm{~m}^{2}$ and a volume of some $50000 \mathrm{~m}^{3}$ (Fig. 3). During the summer, the lake surface was more or less free of ice, and the water warmed to temperatures of about $2^{\circ} \mathrm{C}$ under the influence of solar radiation and high air temperatures. As shown by strong undercutting of the ice front and drifting of small icebergs away from it, the density increase due to warming triggered a process of thermal convection: warmer and denser surface water sinks to the lake bottom, flows towards the ice front, cools by ice melting and undercutting the ice front, thereby reducing its density, and rises again to the lake surface where it flows away from the ice front and warms up (Fig. 4). Such convection is strengthened by a positive feedback, in that melting of ice leads to a larger surface area of the lake, increased energy input and more melting, etc. This positive feedback together with the existence of massive ground ice represents the main cause for the accelerating lake growth.

During the early 1990s, the last years of its existence, Lake No. 5 grew annually by about $1500 \mathrm{~m}^{2}$ in surface area and $7500 \mathrm{~m}^{3}$ in volume. On two occasions in the 1980s, the lake level smoothly dropped by several meters without leaving 


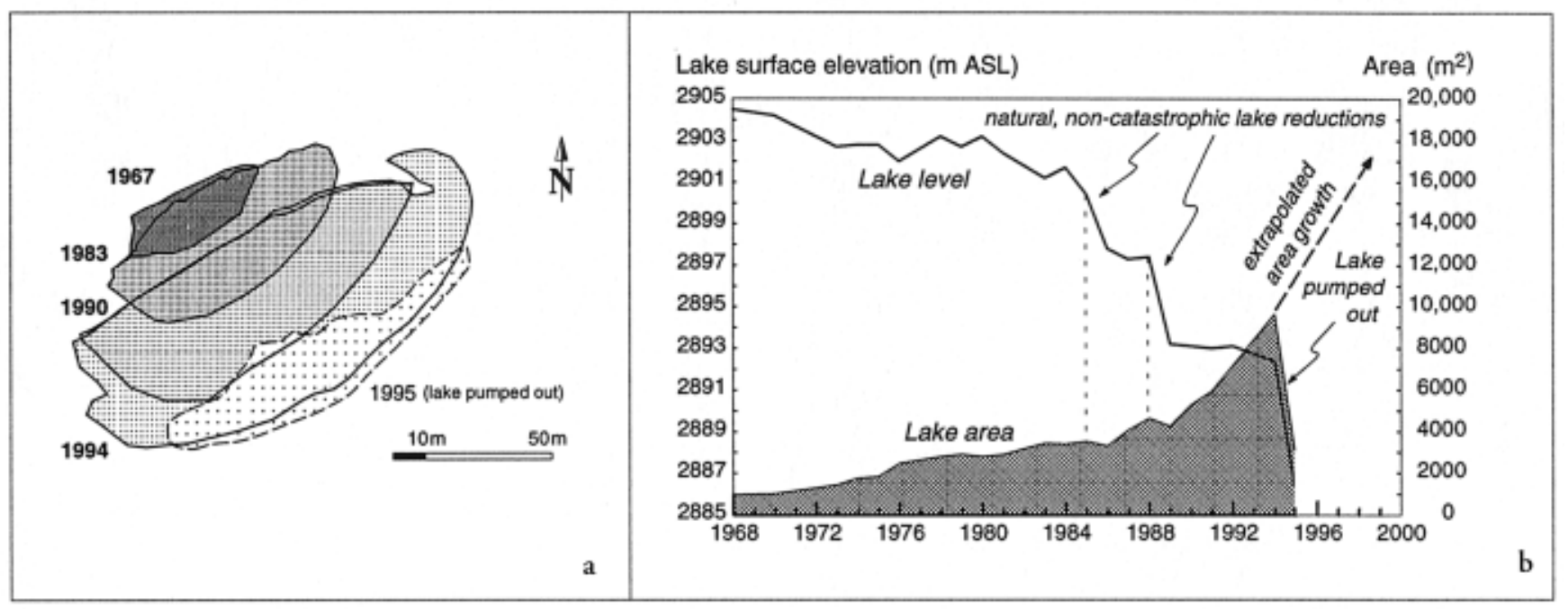

Fig. 3. Growth of thermokarst Lake No. 5. ( a) Planimetric representation of the lake outline in selected years of the time period 196795 (note asymmetric lake growth towards the massive ground ice in the south; the sudden displacement of the northern lake shore is a consequence of the lake-level lowering in 1984). (b) Lake level and area over the period 1968-95. Lake level smoothly dropped some meters in 1985 and 1988; assessment of future lake growth suggested an area of about $20000 \mathrm{~m}^{2}$ or a volume of $100000 \mathrm{~m}^{3}$ in the year 2000 (dashed line with arrow). In 1995, the lake was pumped out due to its increasing hazard potential.

any traces of surface runoff. These changes in lake level pointed to the existence of near-surface crevasses in the surrounding ice and permafrost, but the corresponding water losses did not significantly slow down the overall growth rate of the lake (Fig. 3). Photogrammetrically measured differential melt, subsidence and flow rates (Fig. 2; Kääb and others, 1997) indicated that massive ground ice at the southern lake border continued right into the steeper slope towards Lake No. 3 where creep is accelerating (extending flow). Extrapolated lake growth would have reached this critical area with potential crevasse formation and fast lowering of the southern lake shore in the years 1998-2000 at the latest (cf. Fig. 3b). It was therefore decided to determine the geometry of the lake bottom from a rubber boat, using a microdigitizer echo-sounder in combination with a tachymeter and later a differential real-time global positioning system receiver. A total of 4200 points were measured with an estimated accuracy of $\pm 0.1 \mathrm{~m}$. Based on this information and the photogrammetric data, the area and volume of the lake at the expected outburst time were estimated at $20000 \mathrm{~m}^{2}$ and $100000 \mathrm{~m}^{3}$, respectively. A sudden outburst of such volumes

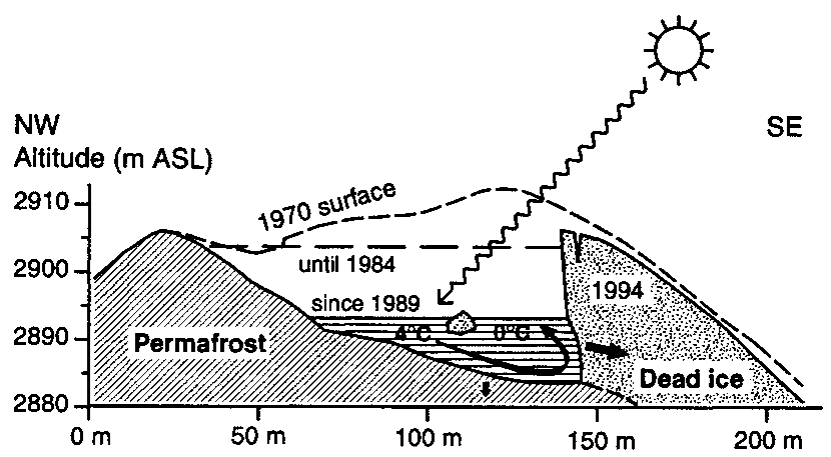

Fig. 4. Schematic representation of energy input by solar radiation, convective heat transport to the damming front of buried massive ice, subsequent ice melt and water cooling of the lake water leading to a positive feedback which drives the non-linear growth of thermokarst Lake No. 5. After drainage of the lake, strong undercutting and vertical pear-like convexities of about $1 \mathrm{~m}$ height were found in the exposed ice front, presumably related to local thermic convection cells. could have produced peak discharges of several $\mathrm{m}^{3} \mathrm{~s}^{-1}$ (cf. Haeberli, 1983), potentially triggering outbursts of Lakes No. 3 and 1 with corresponding debris-flow hazards at Lake No. 1 , at the rock glacier front or on steep slopes lower down. The recognizable hazard potential from the quickly enlarging Lake No. 5 was therefore considered to be unacceptable (cf. further comments in the section on hazard-mitigation works).

\section{Ice-marginal Lakes No. 4, 3 and 2}

The topographic depression at the right glacier margin contains the ice-dammed Lakes No. 4, 3 and 2 (Fig. 1), the development and safety of which are strongly affected by changes in mass and geometry of the glacier.

Lake No. 4 started to grow in the late 1960s up to an area of some $5000 \mathrm{~m}^{2}$ in the mid-1970s. During the following years of general glacier growth, the related depression was mostly filled year-round by snow and ice. From the late 1980 s on, the lake enlarged again by successively melting towards the glacier, reaching an area of $6000 \mathrm{~m}^{2}$ in the mid1990s. Almost every year, Lake No. 4 slowly emptied in late fall. The normal lake drainage towards Lake No. 3 is partially along and partially beneath the glacier margin. Presently, Lake No. 4 is growing from its flat sediment bottom towards thicker ice and steeper, rocky parts of the glacier bed. Formation of slush avalanches in snow covering the outflow can cause suddenly increased discharge towards Lakes No. 3 and 1 during spring and early summer. However, the lake has remained empty during the past few years.

The outbursts of Lake No. 3 in 1968 and 1970 (Röthlisberger, 1979) had occurred when the lake water rose to the flotation threshold of the damming ice and snowdrift, triggering subglacial drainage and progressive enlargement of a subglacial channel during early summer (cf. Nye, 1976, for the principle of the outburst mechanism). After artificial waterlevel regulation via a subglacial drainage pipe, the lake was stabilized until recent years when the surface of the ice dam started to sink and approach the flotation threshold from above. Such a potentially dangerous situation had been anticipated on the basis of careful monitoring by regular visual inspection and photogrammetric analysis of the specially 
flown annual air photos. Between 1976 and 1989, the slightly advancing glacier had reduced the area of the lake surface (Fig. 5). More recently, glacier shrinkage enabled renewed increase in lake surface area by melting and undercutting of the calving ice front (cf. Haeberli and Röthlisberger, 1976; Iken, 1977). In 1996, the lake surface area had reached $18000 \mathrm{~m}^{2}$. A collapse structure in the ice, visible on air photos since 1994, indicated that the lake water had begun to melt a large cavity underneath the glacier, probably in connection with water from Lake No. 4 flowing over morainic material and entering the eastern part of Lake No. 3. The total lake volume could, therefore, only roughly be estimated at about $100000 \mathrm{~m}^{3}$ (for 1996). The lake had not always been completely full during the air-photo flights in the fall, a fact which must be taken into account when interpreting the evolution of the photogrammetrically mapped lake surface.

The safety of the ice dam at Lake No. 3 depends on the height of the ice surface above lake level. This geometry critically depends on ice advection by glacier flow which, in turn, is a function of the mass-balance evolution of the entire glacier. Recent mass changes of the entire glacier up to the summit of Fletschhorn were determined by photogrammetric analysis of high-altitude flights (Kääb, 2000) carried out by the Swiss Federal Office of Topography at time intervals of several years for the standard revision of the Swiss National Topographic Map. As compared to the time interval 1975-85 with predominant volume increase especially in the lower glacier part, the time interval 198591 is characterized by average thickness losses of $-0.8 \mathrm{~m} \mathrm{a}^{-1}$ (Fig. 6), a value which is in good agreement with similarly strong mass losses measured directly at other Alpine glaciers (Haeberli and others, 1999b).

Information from the annually flown low-altitude air photos (Kääb, 2000) showed that the velocity of ice flow on the glacier tongue at Lake No. 3 (Figs 7 and 8) had reached a maximum around 1980 and then dropped by about $50 \%$ until 1994. This drastic reduction of flow velocity is only partially correlated with changes in ice thickness (cf. Fig. 8), probably due to changes in the subglacial water pressure. It caused the ice dam at Lake No. 3 to lower after 1985, i.e. 5 years after the velocity maximum in 1980, at a rate of $-1.5 \mathrm{ma}^{-1}$ on average with an extreme value of $-3 \mathrm{ma}^{-1}$ in 1990. In 1994, the ice surface was lower than in the years of

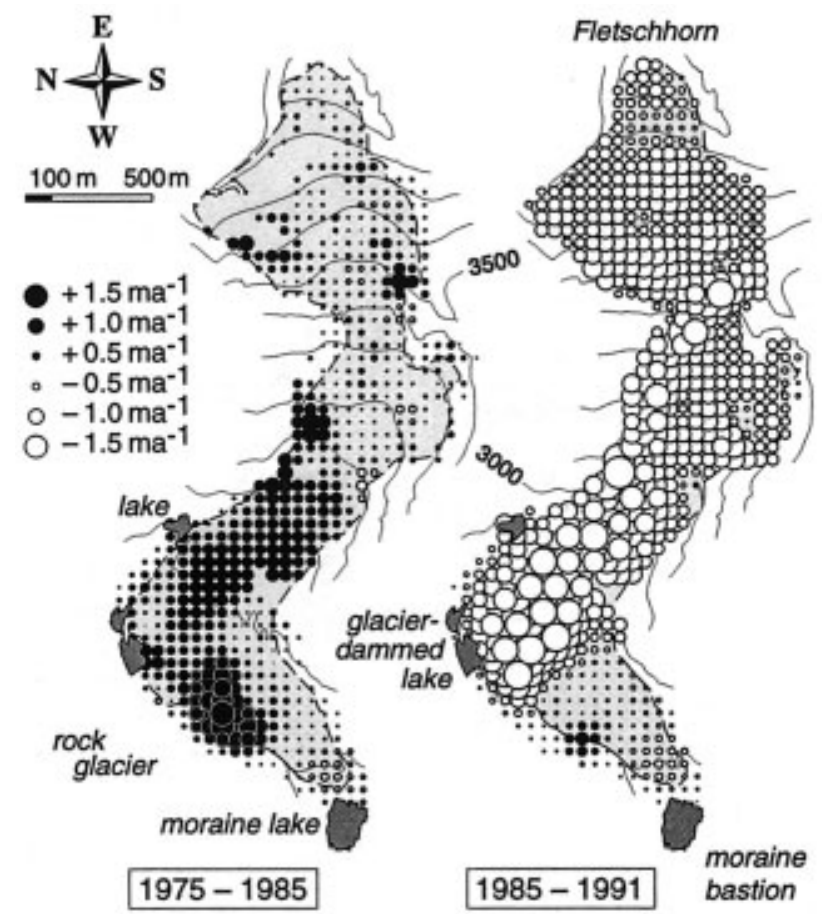

Fig. 6. Spatial pattern of mean annual changes in surface elevation of Grubengletscher during the time intervals 1975-85 (left) and 1985-91 (right). The results were derived from regularspaced photogrammetrically measured digital terrain models (DTMs) (50 m grid) of 1975, 1985 and 1991. Note the strong increase in surface elevation affecting the lower part of the glacier tongue and indicating an advance between 1975 and 1985 followed by decrease in ice thickness from 1985 to 1991.

the lake outbursts in 1968 and 1970 and at the time of artificial lake-level regulation. In view of such developments, imminent reversal of the ice-thinning trend near Lake No. 3 could not be assumed.

Ice depth near Lake No. 3 is known from radio-echo soundings and hot-water drillings which were combined with subglacial d.c. resistivity soundings using borehole electrodes (Haeberli and Fisch, 1984). Based on this information and the above-mentioned photogrammetric data, the safety against dam failure was calculated as the excess thickness above the critical flotation threshold (Fig. 9). In the fall of

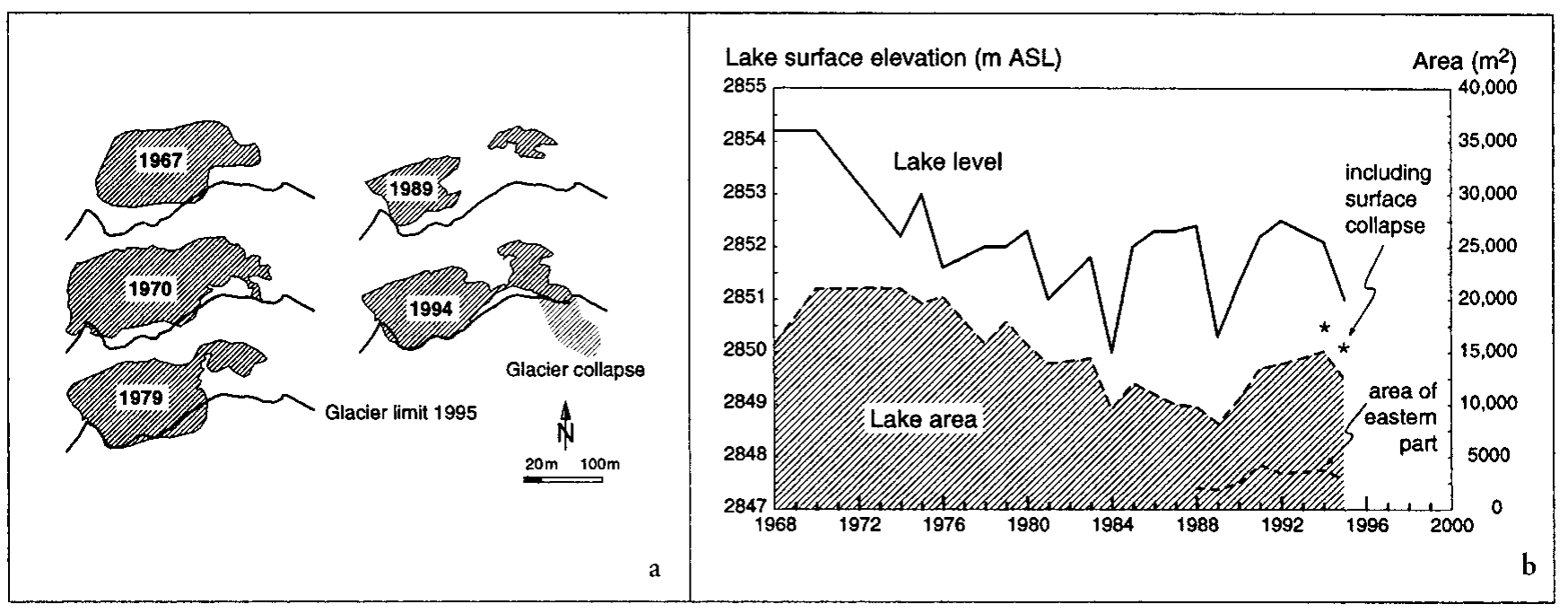

Fig. 5. Evolution of ice-dammed Lake No. 3 during the time period 1968-95. (a) Planimetric representation of the lake outline at selected times of photography, 1967-94. (b) Lake level and area as a function of time. Note that lake level is varying over time. The presented values only reflect the situation at the time of aerial photography in the fall. 


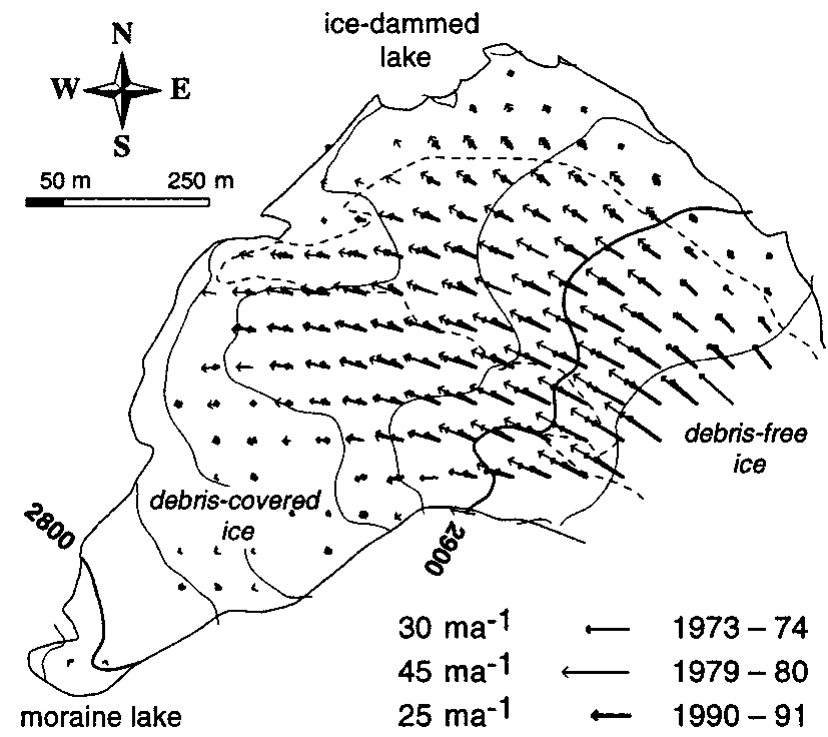

Fig. 7. Field of mean annual velocities on the tongue of Grubengletscher during the time intervals fall 1973-fall 1974, fall 1979-fall 1980 and fall 1991-fall 1992. The average surface velocity dropped drastically between the latter two stages, presumably due to marked changes in subglacial water pressure.

1995, this safety reached a minimum of $8 \mathrm{~m}$ at the thinnest point of the ice dam. By extrapolating the observed subsidence rates $\left(-1.5\right.$ to $\left.-3 \mathrm{~m} \mathrm{a}^{-1}\right)$ of the ice surface, a potential
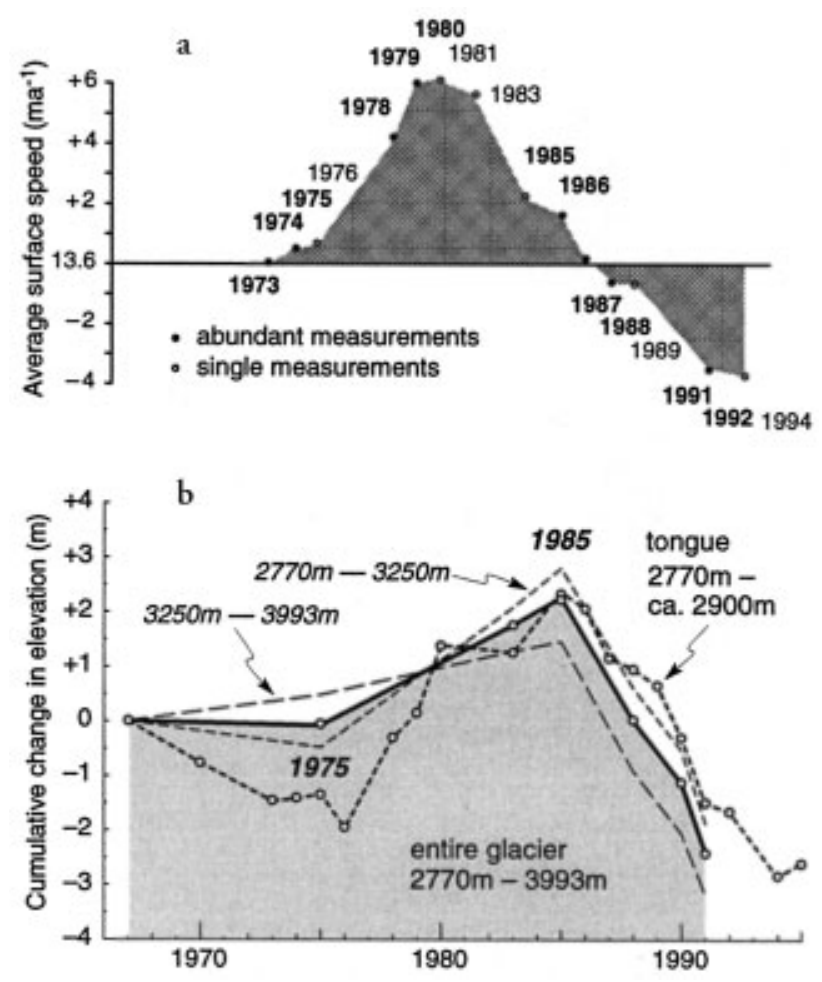

Fig. 8. Change in flow velocity and surface elevation on the tongue of Grubengletscher during the time interval 1973-92. (a) Cumulative changes in mean annual velocity. Bold data points indicate high-precision results from redundant and independent photogrammetric measurements; unfilled ones indicate single measurement procedures. (b) Cumulative changes in average elevation of the entire Grubengletscher (filled area) and its tongue (dotted line), 1967-91 (196795 for the tongue). Due to the limited availability of high-altitude aerial photographs covering the entire glacier, DTMs could be collected only in selected years, whereas a DTM of the tongue region could be measured almost every year.

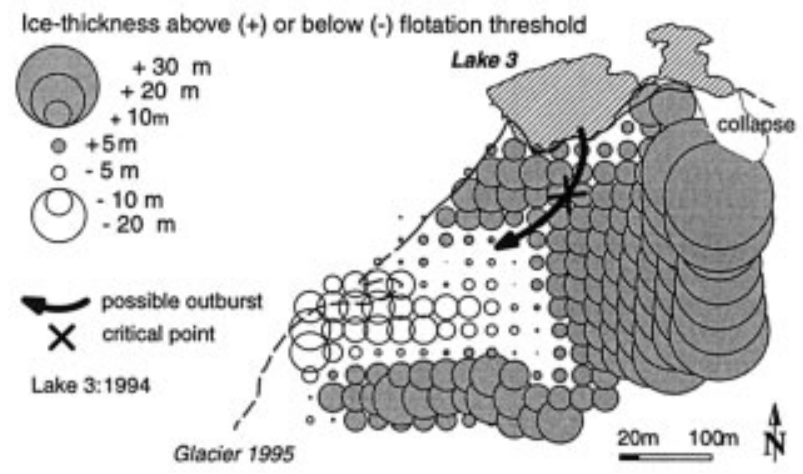

Fig. 9. Safety of ice-dammed Lake No 3 in 1995: ice thickness above flotation threshold was calculated from glacier bed topography determined by radio-echo sounding, photogrammetryderived ice-surface topography and extrapolated lake level applying the "iceberg model" of Nye (1976).

early outburst time was estimated as 1998-2000. It was therefore considered advisable to undertake the necessary steps for avoiding another uncontrolled lake drainage (cf. further comments in the section on hazard-mitigation works).

Lake No. 2 was situated at the right margin of the heavily debris-covered part of the glacier tongue (Fig. 1). Its area was continuously reduced by the growing glacier (cf. Fig. 6) from some $2000 \mathrm{~m}^{2}$ in 1975 to its complete disappearance in 1981 .

\section{Proglacial Lake No. 1}

Lake No. 1 grew on top of a very thick sediment bed or morainic apron. Such thick morainic beds form where glaciers receive much more debris from the surrounding rock walls than the meltwater stream can evacuate (Haeberli, 1996; Maisch and others, 1999). As a positive feedback, they reduce the transport capacity of meltwater streams through percolation of surface water into the subsurface or through lake formation in closed topographic depressions. Lakes thus formed represent an obvious potential for moraine-dam breaching and the formation of large debris flows. At Gruben, the flood events of 1968 and 1970 had initiated the breaching process in the morainic apron, and an artificial dam consisting of coarse blocks with a concrete outlet structure had to be installed in order to prevent further incision and debris-flow formation in the eroded stream channel.

During recent years, hydrogeological conditions at Lake No. 1 have undergone remarkable changes. Lake level more and more remained below the artificial dam and only reached the concrete outlet during time periods of strong ice melt combined with events of heavy precipitation. Water leaving Lake No. 3 drained into coarse, highly permeable morainic deposits before entering Lake No. 1. Moreover, the southern part of the lake (Fig. 1) quickly enlarged into dead ice buried within material of the 1890/1920 moraines but only filled when water from the northern lake part was flowing over a threshold between the two parts. This development was favourable in that it increased the potential retention volume of Lake No. 1 with respect to unexpected floods from upstream lakes and ponds. However, it also created concern among the local population that the stability of the moraine dam could degrade due to internal erosion or ice melt. This concern was later substantiated by the observation made during one event of heavy precipitation and fast-rising lake level, that percolating water was flowing underneath the outlet structure to reappear as strong springs in the moraine 
breach on the valley side. The stability of the moraine dam is, indeed, a crucial component of the hazard potential in the entire drainage basin, because the retention capacity of Lake No. 1 essentially helps protect the village of Saas Balen from the formation of dangerous debris flows in the eroded stream channel but could most seriously aggravate the danger in case of dam failure. Geophysical, hydrological and photogrammetric investigations were therefore carried out on the huge morainic apron in order to investigate the stability aspects and to redesign the protective measures.

\section{Characteristics and stability of morainic materials at Lake No. 1}

Breaching of moraine dams may involve (a) piping (progressive ground-water flow) within the morainic material, (b) liquefied flow/slippage on steep slopes, and (c) overtopping with retrogressive incision (Haeberli, 1992, 1996; cf. Youd and others, 1981). In all cases, high water levels are critical and the internal structure, the porosity and the water saturation within the morainic material constitute the main factors influencing the stability. The primary questions to be answered by the investigations, therefore, related to trajectories of subsurface water flow and to the presence or absence of ground ice, of loose erodible material and of watersaturated sediments.

Three seismic refraction profiles and 13 geoelectrical d.c. resistivity soundings were measured in 1993 by GEOTEST Consulting Company (Geotest, unpublished; Figs 1 and 10). Geoelectrical d.c. resistivity of (unfrozen) bedrock was determined to be about $9 \mathrm{k} \Omega \mathrm{m}$ at outcrops near the foot of the moraine slope. The internal moraine structure (Fig. 10) was analyzed using characteristic values for seismic velocities and d.c. resistivities usually observed in starting zones of debris flows (Haeberli and others, 1990). In addition, the ratio $\rho(\Omega \mathrm{m}) / V_{\mathrm{p}}\left(\mathrm{m} \mathrm{s}^{-1}\right)$ between the electrical resistivity $\rho$ and the seismic velocity $V_{\mathrm{p}}$, multiplied by a factor $R$ reflecting the vertical sequence of resistivities, was also considered (Vonder Mühll and others, 1996). Gravimetric observations were made in 1994. Determination of the regional gravity field requires measurements on outcropping bedrock on each side of the expected anomaly, here the morainic layers. This task was made difficult by the fact that nearby rock outcrops hardly exist in the eastern part of the investigated area. Hydrological investigations were carried out in 1993 and 1994.

The seismic refraction soundings indicated bedrock as a marked refractor with P-wave velocities of $3900-4900 \mathrm{~m} \mathrm{~s}^{-1}$ (Fig. 10). Bedrock depth is only a few meters at the foot of the moraine dam but increases continuously towards Lake No. 1 where it reaches $100 \mathrm{~m}$ and more. Within the uppermost 5$20 \mathrm{~m}$ of the moraine, seismic velocities are $400-900 \mathrm{~m} \mathrm{~s}^{-1}$ and resistivities are 2 to $>15 \mathrm{k} \Omega \mathrm{m}$ in places. Deeper morainic layers are characterized by seismic velocities of 1000-1700 $\mathrm{m} \mathrm{s}^{-1}$ and resistivities of $2-8 \mathrm{k} \Omega \mathrm{m}$. The highest resistivity values are correlated with very low seismic velocities, indicating large porosity rather than ground ice (which would have high seismic velocities). Particularly loose parts of the moraine therefore occur relatively close to the surface, whereas indications for ground-water-bearing layers are sparse and concentrated at the interface between bedrock and the moraine.

With total thickness and internal structure of the moraine being known from the seismic and geoelectrical soundings, gravimetry was applied to estimate density and porosity of the morainic material. As the gravity map of Switzerland (Klingelé and Olivier, 1980) gives small gradients in the investigated area, the interpretation of the long profiles is based on the assumption that the regional gravity field is horizontal $(-156.0 \mathrm{mgal})$. The resulting Bouguer anomaly for the moraine area is $-1.2 \mathrm{mgal}$ (Fig. 11), and the corresponding density contrast about $0.3 \mathrm{Mg} \mathrm{m}^{-3}$. Bedrock density was measured, using local samples, as $2.76 \mathrm{Mg} \mathrm{m}^{-3}$, giving an average density $(\rho)$ of the moraine of roughly $2.4-$ $2.5 \mathrm{Mg} \mathrm{m}^{-3}$, and a mean porosity $(n)$ of $11 \%$ in air/rock mixtures and of $17 \%$ in water/rock mixtures. Such a low

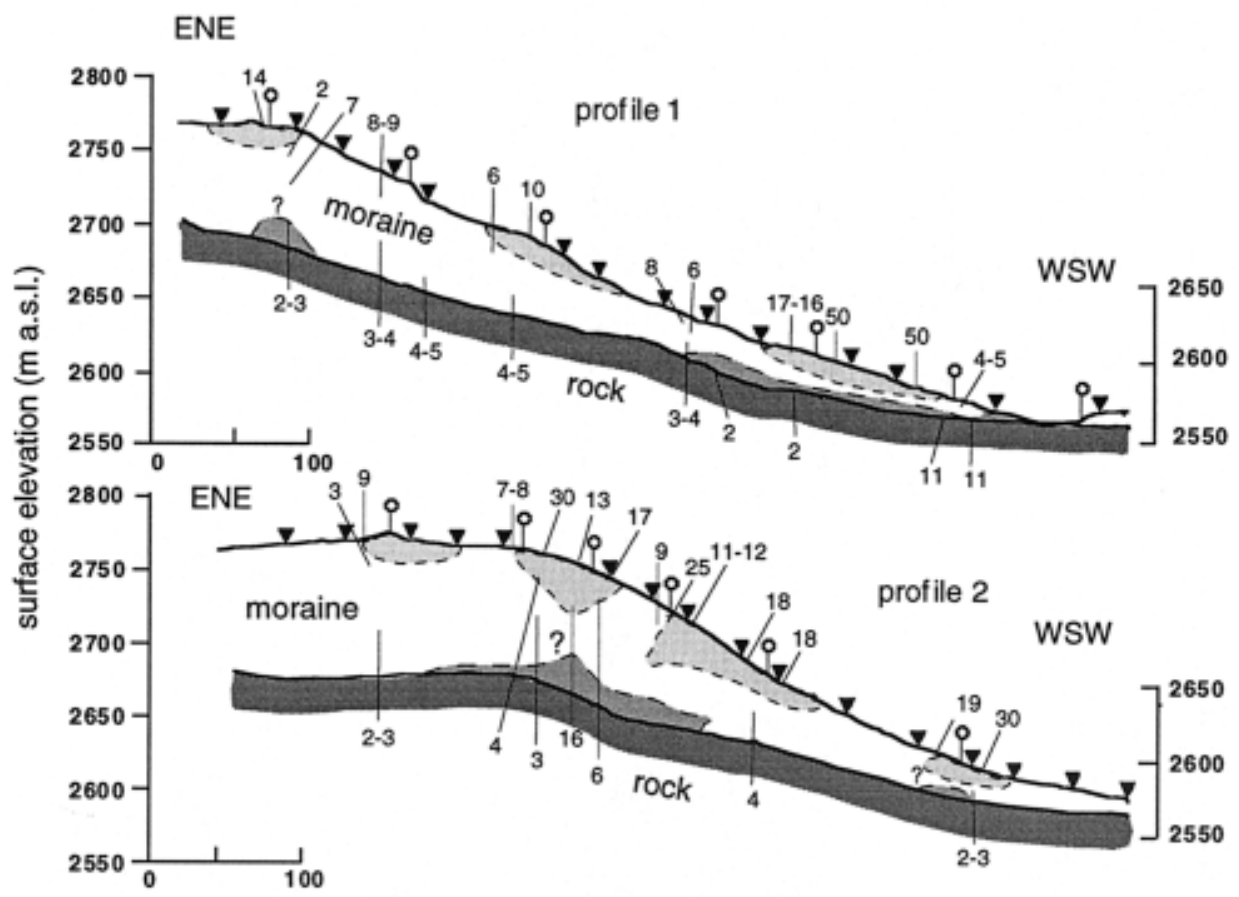

Fig. 10. Two sections through the moraine dam near Lake No. 1 as obtained from seismic refraction and d.c. resistivity soundings. Numbers refer to an index combining the results from the two sounding methods mentioned in the text. The light-dotted area shows loosely compacted layers, the darker-dotted area represents possible occurrences of ground water, and the remaining parts are nonsaturated and well-compacted morainic material. 


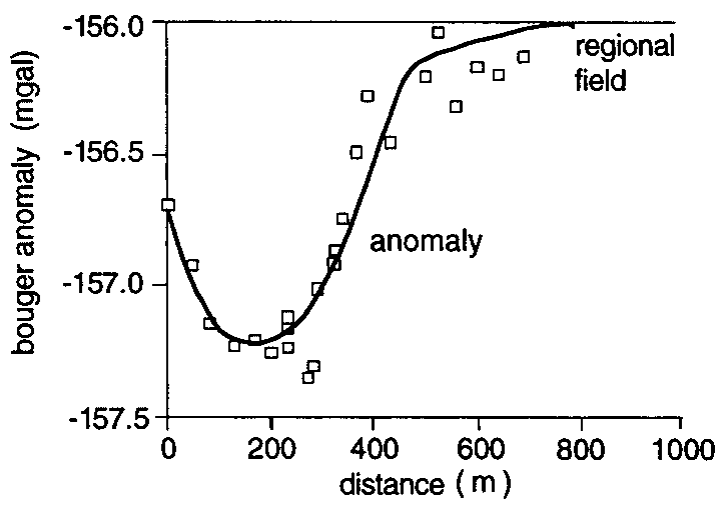

Fig. 11. Regional and residual gravity field of a profile across the moraine dam along profiles $P_{1}$ and $P_{2}$ in Figure 1. (Lake $\mathcal{N}$ o. 1 is to the left, and the bottom of the moraine to the right of plot) assuming a constant regional field of $-156.0 \mathrm{mgal}$. The residual anomaly is up to $-1.2 \mathrm{mgal}$.

mean porosity points to a good overall consolidation with large amounts of fine sand, a phenomenon indeed observed in the subglacial channel excavated for the artificial drainage of Lake No. 3.

Concerning the internal structure of the moraine as indicated by the results from the seismic and resistivity soundings, the entire deposit was treated in a second step as consisting of three main layers: the deepest layer was assumed to be water-saturated and to have average density, the intermediate layer to have air-filled pores and average density, and the uppermost layer to have air-filled pores but unknown density. A corresponding sensitivity study using variable thicknesses for the deepest and uppermost layer showed that near-surface layers of the moraine can have high to extremely high porosities if not real caverns, possibly from melting of buried ice or permafrost (Vonder Mühll and others, 1996). In fact, such a cavern with a diameter in the meter range had already been encountered during original construction work for the dam consisting of coarse blocks at Lake No. 1 where ice lenses had previously been found in an exploratory core drilling (cf. Haeberli, 1992). Thaw settlement from dead-ice melting is known to occur to the south of Lake No. 1, where photogrammetric analysis for the time interval 1976-94 indicates terrain subsidence at rates up to $0.3 \mathrm{~m} \mathrm{a}^{-1}$ (Kääb, 1996). Near the dam, however, the applied spacing for measurements of $25 \mathrm{~m}$ showed no significant changes in surface altitude.

Tracer experiments together with discharge and temperature measurements at the main springs of the area (Fig. 1) were carried out by members of ETH Zürich in June 1993 and by the University of Fribourg in June-August 1994 (Gardaz and Lugon, unpublished; Speck, unpublished). The tracer experiments were difficult to interpret: fluorescine dye was injected where the meltwater stream between Lakes No. 3 and 1 disappeared into the ground, but reached two springs at the foot of the moraine apron in weak concentrations and only after several days. It must be assumed that the meltwater stream enters deeper layers of Lake No. 1 and that the dye had been dissolved by the lake volume and adsorbed by fine sediments at the lake bottom. Because discharge in the meltwater stream as measured by the salt dilution method corresponds to the discharge of the main spring at the foot of the moraine (A in Fig. 1), water from the northern part of Lake No. 1 must be connected with this main spring but percolates and flows through the moraine with velocities of $10^{-3}$ to $10^{-2} \mathrm{~m} \mathrm{~s}^{-1}$.

Water from the southern part of Lake No. 1 is connected to a number of smaller springs (B in Fig. 1) in the southern part of the moraine apron, which provide water with a delay of several days after the onset of overflow from the northern into the southern part of Lake No. 1 and the filling of the latter. This observation confirms the slow subsurface flow velocities estimated by the tracer experiments, and thus the generally low porosity of deeper layers in the moraine as indicated by the geophysical soundings. The bottom of the southern lake part is covered by a silty layer about $0.1-0.2 \mathrm{~m}$ thick. This layer is eroded where water from the northern lake part enters the depression of the southern lake part (Fig. 12). Because a discharge of $0.04 \mathrm{~m}^{3} \mathrm{~s}^{-1}$ filled the southern section of the lake within about 1 day, percolation into the underlying moraine via the gullies eroded into the silty lake bottom must be considerably less. Comparison with the total volume of the southern lake section $\left(1-2 \times 10^{3} \mathrm{~m}^{3}\right)$ indicates a percolation rate of about $0.02 \mathrm{~m}^{3} \mathrm{~s}^{-1}$. Characteristic water temperatures of springs $\mathrm{A}$ and $\mathrm{B}$ were around $3^{\circ} \mathrm{C}$. Since the water probably flows at depths between several tens of metres and $100 \mathrm{~m}$ below the surface, average temperatures inside the moraine apron are assumed to be $0-3^{\circ} \mathrm{C}$. Given considerably colder temperatures during the Little Ice Age and maximum glacier advance around 1850 (Haeberli and Beniston, 1998; Maisch and others, 2000), it is highly probable that upper layers of the moraine apron had, at that time, been frozen underneath the cold glacier margins of the more extended polythermal glacier. Degradation of former subglacial permafrost with melting of ground ice could explain the weakly consolidated near-surface layers detected by the geophysical soundings. Permafrost still exists in an inactive, south-exposed rock glacier east of the moraine apron (Haeberli and others, 1979). The corresponding spring ( $\mathbf{C}$ in Fig. 1) has a temperature of about $1.5^{\circ} \mathrm{C}$, a value which is typical for permafrost drainage.

The combined consideration of all collected evidence shows that the moraine apron at Lake No. 1 (a) is up to $>100 \mathrm{~m}$ thick, (b) today contains no large bodies of buried ice or perennially frozen ground, but (c) could have been frozen in surface layers covered by the polythermal and more extended glacier tongue during the maximum stage of the Little Ice Age, (d) now has extremely loose parts near the surface, probably as a consequence of glacier retreat and permafrost degradation during the 20th century, (e) is well consolidated at greater depth, (f) only contains relatively thin water-saturated layers at the contact between the moraine and bedrock, and (g) discharges water from Lake No. 1 at great depths and slow rates. With respect to the safety of Lake No. 1, it was concluded that the $25-35^{\circ}$ steep outer slope of the moraine dam as a whole could be considered stable against deep-seated sliding because of the low water saturation and good consolidation. It was, however, also clear that the loose material near its surface could be easily eroded by piping, shallow slope instability, backward incision of the breach or debris flows, possibly even in a combination of such processes with positive feedbacks between them. Hence, use could be made of the retention capacity represented by the lake basin, but uncontrolled flooding at the lake outlet and discharge of large water masses across the open moraine slope would have to be avoided. 


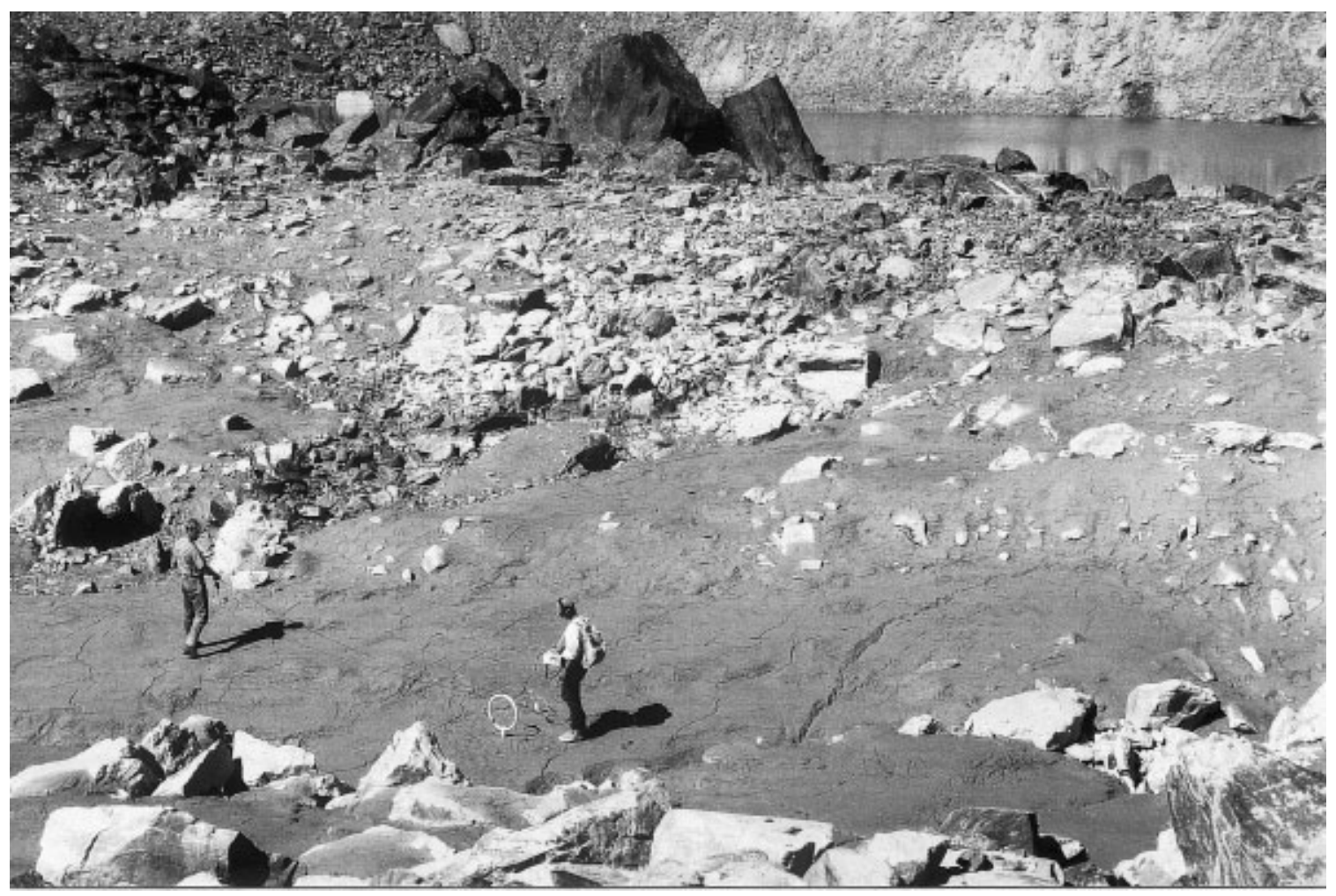

Fig. 12. Silty bottom of empty southern part of Lake No. 1; the view is towards the threshold between the southern and northern lake parts. Note small channels eroded to the gravelly bed (photo W. Haeberli, September 1992).

\section{HAZARD-MITIGATION WORKS}

Based on the observations and measurements described above, it was assumed that

(1) thermokarst Lake No. 5 could soon drain in a dangerous way;

(2) the tongue of Grubengletscher would continue to shrink by downwasting rather than by retreat;

(3) Lake No. 3 would grow more and more in surface area and volume;

(4) the ice dam at Lake No. 3 could soon lower to the flotation threshold;

(5) future unforeseeable events could cause Lake No. 1 to spill over its dam consisting of coarse blocks and flood the steep, loose outer slope of the damming moraine; and

(6) internal erosion (piping) of loosely packed morainic material at the outlet structure of Lake No. 1 is conceivable in the case of high water level.

A hazard-mitigation scheme was therefore developed in cooperation with the authorities of the Community of Saas Balen, the Canton of Valais and the Swiss Confederation to prevent the future evolution of dangerous situations. This scheme was designed in such a way that the measures account for the special geotechnical conditions (ground ice, unfrozennon-consolidated material), are adaptable to the rapidly changing situation and make best possible use of naturally occurring processes. The core of this strategy involved the decision to artificially empty Lake No. 5, to open a new periglacial outlet for Lake No. 3 and to enlarge the retention capacity of Lake No. 1 by deepening and reinforcing its outlet structure.

For the controlled emptying of Lake No. 5, pumping, syphoning, oblique drilling or tunnelling through the ice dam and construction of a V-shaped ditch were considered. In the fall of 1995, the lake was emptied almost entirely by pumping. This immediate but temporary measure gave the necessary time to effect measures at the lower Lakes No. 3 and 1 without flood risks from Lake No. 5 (Kääb and others, 1996). The slowly refilling Lake No. 5 was definitively drained in 1997 by the construction of a roughly $10 \mathrm{~m}$ deep $\mathrm{V}$-shaped ditch. The formation of this ditch was initiated by artificial excavation of a slightly inclined channel down to the lake level and completed by downcutting through massive ground ice by the outflowing water.

The growing risk of large water volumes bursting out from Lake No. 3 was eliminated by lowering the lake level and reducing the lake surface area and volume. This was accomplished in summer 1996 by opening an approximately $2 \mathrm{~m}$ deep channel along the glacier margin and creating a periglacial outlet through the contact zone between the glacier and the rock glacier (Fig. 13). Removal of large, thermally insulating blocks of rock from the surface, and the

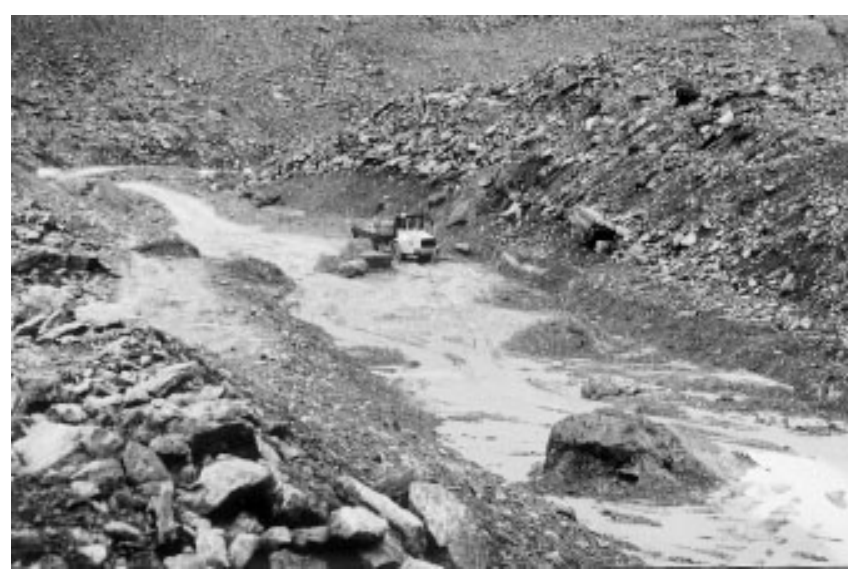

Fig. 13. Excavation of a drainage channel for ice-marginal Lake No. 3 (photo A. Kääb, 1995). 
effect of water running through the excavated channel may melt remains of frozen ground and enable continuous natural erosion of the channel to increasing depth, thereby further lowering lake level and volume. The excavated material was deposited in the lake and reduced its area and volume to a fraction of its original values.

The overflow level of Lake No. 1 was lowered by about $2 \mathrm{~m}$ in summer 1996. The discharge capacity of the narrow concrete spillway through the existing dam (Fig. 14) consisting of coarse blocks is limited with regulating gates to $3 \mathrm{~m}^{3} \mathrm{~s}^{-1}$ in its lower part. This enables controlled outflow during events of suddenly rising lake level, and enlarges the retention capacity of the lake basin by about $50000 \mathrm{~m}^{3}$. Inflow to, and outflow from, the outlet structure as well as the geometry of the foreland on the water side were adjusted by earthwork. During the fall of the same year, a grout curtain was created by injecting concrete through $10 \mathrm{~m}$ deep boreholes with a $1 \mathrm{~m}$ spacing. As a result, percolation distances underneath the dam consisting of coarse blocks became longer, reducing the hydraulic gradient and the potential for piping underneath the outlet structure. Ground-water levels are being observed on both sides of the grout curtain. The continuation of direct observations and special air-photo flights form an integral part of the hazard-mitigation scheme and should enable appropriate steps to be taken in time and according to the changes documented in the future.

\section{CONGLUSIONS AND PERSPEGTIVES FOR THE FUTURE}

The work carried out at Grubengletscher described here illustrates the possibilities of early recognition, analysis and prevention of hazards arising from outbursts of periglacial lakes and resulting debris flows in high mountain areas. The combination of aerophotogrammetric analysis and geophysical ground-probing techniques proved especially useful with respect to judging ongoing developments, delineating possible future evolution and assessing geotechnical conditions for the installation of protection works. Long-term monitoring by direct observation and air-photo flights forms an invaluable planning basis under continuously changing ice conditions. In a scenario of future atmospheric cooling and glacier growth, situations would develop which are comparable with those now documented for the past decades. In a scenario of continued or even accelerated warming, however, the tongue of Grubengletscher could thin beyond avail-

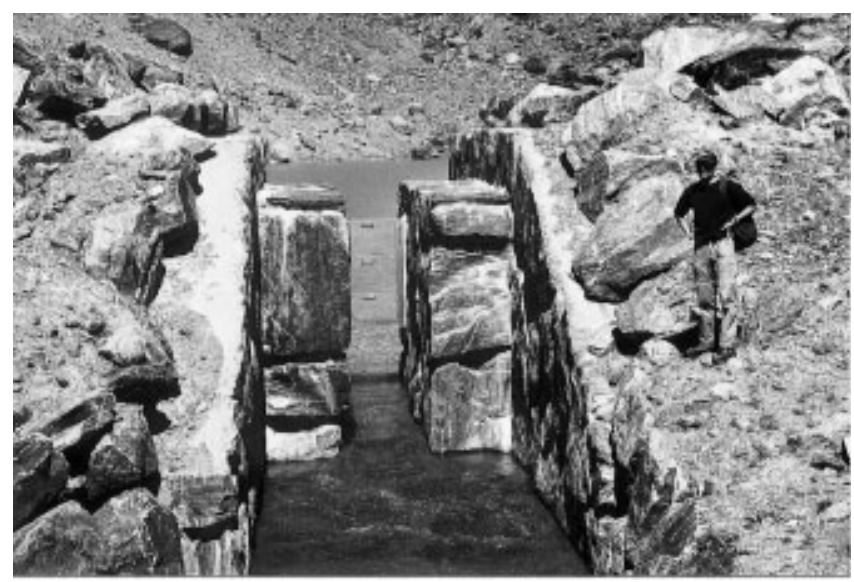

Fig. 14. New (lowered) flood-release (overflow) structure with regulating gates at proglacial Lake No. 1 (photo W. Haeberli, July 2000). able experience and even completely disappear. As a consequence, large water volumes partially dammed by (cold?) ice and frozen ground could collect in the area of the overdeepened glacier bed. Such a potentially hazardous development would be without historical precedent but could be recognized at an early stage on the basis of an adequate observation system.

The hazard-prevention project at Grubengletscher combined well-established with newly developed methods and techniques. It is hoped that the experience from the investigation at Grubengletscher provides some help and guidance for comparable cases which may develop at other mountain sites.

\section{ACKNOWLEDGEMENTS}

This work was a common effort of the University and ETH Zürich, the Community of Saas Balen, the Canton of Valais, the Swiss Confederation and the Swiss National Science Foundation through project No. 4031-034232 (Ice Melting and Natural Catastrophes in High Mountain Areas) of the Swiss National Research Programme 31 (Climate Change and Natural Catastrophes). The authorities and colleagues involved are gratefully acknowledged, and to the population of Saas Balen we express our deepest appreciation and thanks for collaboration and help. S. G. Evans (Geological Survey of Canada) and M. Jakob (EBA Engineering, Vancouver) provided constructive comments on an earlier version of the paper.

The present contribution is devoted to the memory of Lake No. 5 which had been a fascinating beauty during many years but became increasingly dangerous and had to be destroyed before its natural end. Its disappearance leaves mixed feelings of relief and regret.

\section{REFERENGES}

Barsch, D., H. Fierz and W. Haeberli. 1979. Shallow core drilling and borehole measurements in the permafrost of an active rock glacier near the Grubengletscher, Wallis, Swiss Alps. Arct. Alp. Res., 11 (2), 215-228.

Clague, J. J. and S. G. Evans. 1994. Formation and failure of natural dams in the Canadian Cordillera. Geol. Surv. Can. Bull. 464.

Clague, J. J. and W. H. Mathews. 1973. The magnitude of jökulhlaups. $\mathcal{F}$. Glaciol., 12(66), 501-504.

Clarke, G. K. C. 1982. Glacier outburst floods from "Hazard Lake", Yukon Territory, and the problem of flood magnitude prediction. f. Glaciol., 28(98), 3-21.

Evans, S. G. 1986. The maximum discharge of outburst floods caused by breaching of man-made and natural dams. Can. Geotech. F., 23 (3), 385-387.

Evans, S. G. and J. J. Clague. 1993. Glacier-related hazards and climatic change. In Bras, R., ed. The world at risk: natural hazards and climatic change. New York, American Institute of Physics, 48-60. (Conf. Proc. 277.)

Frauenfelder, R., B. Allgöwer, W. Haeberli and M. Hoelzle. 1998. Permafrost investigations with GIS - a case study in the Fletschhorn area, Wallis, Swiss Alps. Université Laval. Centre d'Études Nordiques. Collection Nordicana 57, 291-295.

Gansser, A. 1983. Geology of the Bhutan Himalaya. Denkschr. Schweiz. Naturforsch. Ges. 96.

Gardaz, J.-M. and R. Lugon. Unpublished. Rapport de l'essai de traçage effectué sur le site de Gruben. Fribourg, Université de Fribourg. Institut de Géographie. Groupe de Recherche en Géomorphologie. (Rapport interne.)

Geotest. Unpublished. Grubengletscher, Saas Balen VS. Seismische und geoelektrische Untersuchungen auf dem Moränendamm beim See Nr. 1. Auftrag Nr. 93092.4.

Haeberli, W. 1975. Überwachung von Kalbungsflutwellen am Grubengletscher, Wallis. Schweiz. Bauztg., 93(43), 694-696.

Haeberli, W. 1980. Morphodynamische Aspekte aktueller Gletscherhochwasser in den Schweizer Alpen. Reg. Basil., 21 (3), 58-78.

Haeberli, W. 1983. Frequency and characteristics of glacier floods in the Swiss Alps. Ann. Glaciol., 4, 85-90.

Haeberli, W. 1985. Creep of mountain permafrost: internal structure and 
flow of Alpine rock glaciers. Eidg. Tech. Hochschule, Zürich. Versuchsanst. Wasserbau, Hydrol. Glaziol. Mitt. 77.

Haeberli, W. 1992. Zur Stabilität von Moränenseen in hochalpinen Gletschergebieten. Wasser, Energie, Luft - Eau, Énergie, Air, 84(11-12), 361-364.

Haeberli, W. 1996. On the morphodynamics of ice/debris-transport systems in cold mountain areas. Nor. Geogr. Tidsskr., 50(1), 3-9.

Haeberli, W. and M. Beniston. 1998. Climate change and its impacts on glaciers and permafrost in the Alps. Ambio, 27(4), 258-265.

Haeberli, W. and F. Epifani. 1986. Mapping the distribution of buried glacier ice - an example from Lago delle Locce, Monte Rosa, Italian Alps. Ann. Glaciol., 8, 78-81.

Haeberli, W. and W. Fisch. 1984. Electrical resistivity soundings of glacier beds: a test study on Grubengletscher, Wallis, Swiss Alps. f. Glaciol., 30(106), 373-376.

Haeberli, W. and H. Röthlisberger. 1976. Beobachtungen zum Mechanismus und zu den Auswirkungen von Kalbungen am Grubengletscher (Saastal, Schweiz). Z. Gletscherkd. Glazialgeol., 11(2), 1975, 221-228.

Haeberli, W., L. King and A. Flotron. 1979. Surface movement and lichencover studies at the active rock glacier near the Grubengletscher, Wallis, Swiss Alps. Arct. Alp. Res., 11(4), 421-441.

Haeberli, W., J.-C. Alean, P. Müller and M. Funk. 1989. Assessing risks from glacier hazards in high mountain regions: some experiences in the Swiss Alps. Ann. Glaciol., 13, 96-102.

Haeberli, W., D. Rickenmann, M. Zimmermann and U. Rösli. 1990. Investigation of 1987 debris flows in the Swiss Alps: general concept and geophysical soundings. International Association of Hydrological Sciences Publication 194 (Symposium at Lausanne 1990 - Hydrology in Mountainous Regions. II. Artificial Reservoirs: Water and Slopes), 303-310.

Haeberli, W. and 6 others. 1999a. Eisschwund und Naturkatastrophen im Hochgebirge. Zürich, vdf Hochschulverlag an der ETH Zürich. (Schlussbericht NFP 31.)

Haeberli, W., M. Hoelzle and R. Frauenfelder, eds. 1999b. Glacier Mass Balance Bulletin. Bulletin No.5 (1996-1997). Zürich, IAHS(ICSI), World Glacier Monitoring Service; Nairobi, UNEP; Paris, UNESCO.

Hanisch, J., G. Delisle, A. P. Pokhrel, A. M. Dixit, J. M. Reynolds and W. E. Grabs. 1998. The Thulagi glacier lake, Manaslu Himal, Nepal: hazard assessment of a potential outburst. In Eighth International Congress, International Association of Engineering Geology and the Environment, 21-25 September 1998, Vancouver, B.C., Canada. Proceedings. Rotterdam, etc., A. A. Balkema. International Association of Engineering Geology and the Environment, 2209-2215.

Iken, A. 1977. Movement of a large ice mass before breaking off. 7 . Glaciol., 19 (81), 595-605.

Jackson, L. E., Jr, O. Hungr, J. S. Gardner and C. Mackay. 1989. Cathedral Mountain debris flows. Bull. Int. Assoc. Eng. Geol., 40, 35-54.

Kääb, A. 1996. Photogrammetrische Analyse zur Früherkennung gletscherund permafrostbedingter Naturgefahren im Hochgebirge. Eidg. Tech. Hochschule, Zürich.Versuchsanst.Wasserbau, Hydrol. Glaziol. Mitt. 145.

Kääb, A. 2000. Photogrammetric reconstruction of glacier mass balance using a kinematic ice-flow model: a 20 year time series on Grubengletscher, Swiss Alps. Ann. Glaciol., 31, 45-52.

Kääb, A. and M. Funk. 1999. Modelling mass balance using photogrammetric and geophysical data: a pilot study at Griesgletscher, Swiss Alps. 7. Glaciol., 45(151), 575-583.

Kääb, A. and W. Haeberli. 1996. Früherkennung und Analyse glazialer Naturgefahren im Gebiet Gruben, Kanton Wallis, Schweizer Alpen. In Interpraevent 1996, Garmisch-Partenkirchen, Germany, 24-28 June 1996, Internationales Symposion. Munich, Bayerisches Landesamt für Wasserwirtschaft, 113-122. (Tagungspublikation 4.)

Kääb, A., W. Haeberli and P. Teysseire. 1996. Entwicklung und Sanierung eines Thermokastsees am Gruben-Blockgletscher (Wallis). Universität Freiburg, Geographisches Institut, Forschungsberichte, 1996(8), 145-153.

Kääb, A., W. Haeberli and G. H. Gudmundsson. 1997. Analysing the creep of mountain permafrost using high precision aerial photogrammetry: 25 years of monitoring Gruben rock glacier, Swiss Alps. Permafrost and Periglacial Processes, 8(4), 409-426.
King, L., W. Fisch, W. Haeberli and H.P. Waechter. 1987. Comparison of resistivity and radio-echo soundings on rock glacier permafrost. Z Gletscherkd. Glazialgeol., 23(1), 77-97.

Klingelé, E. and R. Olivier. 1980. La nouvelle carte gravimétrique de la Suisse (anomalies de Bouguer). Bern, Kümmerli und Frey. Geographischer Verlag.

Lichtenhahn, C. 1971. Zwei Stollenbauten: Stollen im Eis zur Verhinderung von Ausbruchen eines Sees im Grubengletschergebiet (Wallis) und Stollen im Felsen zur unterirdischen Entwässerung des Rutschgebietes von Camp Vallemaggia (Tessin). In Interpravent 1971, Villach. Vol. 3. 465-475.

Lichtenhahn, C. 1979. Die Verbauung des Fellbachs in der Gemeinde Saas Balen (Wallis). Eidg. Tech. Hochschule, Zürich.Versuchsanst.Wasserbau, Hydrol. Glaziol. Mitt., 41, 169-176.

Lliboutry, L., B. M. Arnao, A. Pautre and B. Schneider. 1977. Glaciological problems set by the control of dangerous lakes in Cordillera Blanca, Peru. I. Historical failures of morainic dams, their causes and prevention. $\mathcal{F}$. Glaciol., 18(79), 239-254.

Maisch, M., W. Haeberli, M. Hoelzle and J. Wenzel. 1999. Occurrence of rocky and sedimentary glacier beds in the Swiss Alps as estimated from glacier-inventory data. Ann. Glaciol., 28, 231-235.

Maisch, M., A. Wipf, B. Denneler, J. Battaglia and C. Benz. 2000. Die Gletscher der Schweizer Alpen: Gletscherstand 1850 - Aktuelle Vergletscherung - Gletscherschwund-Szenarien 21. Jahrhundert. Zürich, v/d/f Hochschulverlag AG ETH. (Schlussbericht NFP 31.)

Nye, J. F. 1976. Water flow in glaciers: jökulhlaups, tunnels and veins. F. Glaciol., $17(76), 181-207$.

O'Connor, J. E. and J. E. Costa. 1993. Geologic and hydrologic hazards in glacierized basins in North America resulting from 19th and 20th century global warming. Nat. Hazards, 8(2), 121-140.

Reynolds, J. M., A. Dolecki and C. Portocarrero. 1998. The construction of a drainage tunnel as part of glacial lake hazard mitigation at Hualcàn, Cordillera Blanca, Peru. In Maund, J. G. and M. Eddleston, eds. Geohazards in engineering geology. London, Geological Society, 41-48. (Special Publication 15.)

Röthlisberger, H. 1971. Massnahmen gegen die Ausbruche eines Gletschersees ob Saas-Balen (Grubengletscher). Schweiz. Bauztg., 89(40), 999-1003.

Röthlisberger, H. 1979. Glaziologische Arbeiten im Zusammenhang mit den Seeausbrüchen am Grubengletscher, Gemeinde Saas Balen (Wallis). Eidg. Tech. Hochschule, Zürich.Versuchsanst. Wasserbau, Hydrol. Glaziol. Mitt. 41, 233-256.

Röthlisberger, H. 1981. Eislawinen und Ausbrüche von Gletscherseen. Fahrb. Schweiz, Naturforschenden Gesellschaft 1978, Wissenschaftlicher Teil, 170-212.

Speck, Ch. Unpublished. Salztracermessungen und Fluoresceinversuche am Grubengletscher (Saas Balen, VS). Zürich, Eidgenössische Technische Hochschule. Versuchsanstalt für Wasserbau, Hydrologie und Glaziologie. (Internal Report.)

Spring, U. and K. Hutter. 1981. Numerical studies of jökulhlaups. Cold Reg. Sci. Technol., 4(3), 227-244.

Suter, S. 1995. Die Verbreitung kalter Firn- und Eisregionen im Alpengebiet. (Diplomarbeit, Eidgenössische Technische Hochschule Zürich.)

Suter, S., M. Laternser, W. Haeberli, R. Frauenfelder and M. Hoelzle. 2001. Cold firn and ice of high-altitude glaciers in the Alps: measurements and distribution modelling. f. Glaciol., 47(156), 85-96.

Vonder Mühll, D., W. Haeberli and E. Klingelé. 1996. Geophysikalische Untersuchungen zur Struktur und Stabilität eines Moränendammes am Grubengletscher (Wallis). In Interprevent 1996, Garmisch-Partenkirchen, Germany, 24-28 June 1996, Internationales Symposion. Munich, Bayerisches Landesamt für Wasserwirtschaft, 123-132. (Tagungspublikation 4.)

Vuichard, D. and M. Zimmermann. 1987. The 1985 catastrophic drainage of a moraine-dammed lake, Khumbu Himal, Nepal: cause and consequences. Mt. Res. Dev., 7(2), 91-110.

Yamada, T. 1998. Glacier lake and its outburst flood in the Nepal Himalaya. Tokyo, Japanese Society of Snow and Ice. Data Center for Glacier Research. (Monograph 1.)

Youd, T. L., R. C. Wilson and R. L. Schuster. 1981. The 1980 eruptions of Mount St. Helens, Washington: stability of the blockage in the North Fork Toutle River. U.S. Geol. Surv. Prof. Pap. 1250, 821-828. 